\title{
The Process of Knowledge Acquisition with the Use of Various Teaching Methods and Its Effect on the Creativity of Employees of the Creative Sector
}

\author{
Dr. Irena Figurska \\ Pomeranian University, Westerplatte 64, 76-200 Słupsk, Poland; Email: irenafigurska@vp.pl \\ Dr. Aneta Sokół \\ University of Szczecin, Cukrowa 8, 71-004 Szczecin, Poland; Email: aneta.dorota@wp.pl
}

\author{
Doi:10.5901/mjss.2016.v7n6p143
}

\begin{abstract}
Contemporary educational process is subject to constant evolution, whose driving force is an on-going process teaching methods development. Transformations regarding the use of various methods in the teaching process arouse cognitive interest in the field of efficient knowledge acquisition among both teachers and learners. Properly assimilated knowledge becomes a source of education determining the quality of professional competence of creative human capital. Today, creativity, which is directly connected with the knowledge and skills of its acquisition, is believed to be one of the most important factors of the human capital development. The main objective of the research was to study and determine the actual use of conventional and unconventional teaching methods in the process of creative human capital development. The article is a literature and empirical study based on different ways of processing materials and their systematization. Furthermore, methods of economic phenomena analysis such as: descriptive, qualitative (comparisons) and quantitative, as well as methods of sociological research (primary and secondary), were used in this article. In order to verify the objective and the research hypothesis, the study was conducted on a group of 911 employees of small and medium-sized entities from the creative sector.
\end{abstract}

Keywords: teaching methods; creative sector; creativity of employees

\section{Introduction}

Knowledge-based economy, which is primarily characterized by increasing globalization, rapid knowledge development and dynamic development of information and communication technologies, brings many challenges for both people and organizations. In such an economy changes occur unexpectedly and are usually difficult to predict. To be able to react to them quickly and wisely, people should systematically broaden their knowledge and skills. In other words, they should be actively involved in the learning process.

Learning means gaining knowledge on a particular topic or skills in a certain area using different methods (Lundy, Cowling, 2000, s. 247). The result of the learning process is a relatively permanent change in the way of perceiving things and behaviours.

Nowadays education is an integral part of the adults' activity, and the processes of learning and teaching never come to the end -learning must be continual, should become a habit, even a lifestyle, and employees who want to remain attractive to employers must take responsibility for systematic learning.

The importance of adult education increases systematically and this trend is definitely not going to change in the foreseeable future. This imposes certain demands on the education system, which must put forward offers, which are attractive both in terms of directions (what to teach?) and forms of education (how to teach?). An offer that meets the needs of: learners, organizations in which they work and the society in which they live.

It should be emphasized that in the knowledge-based economy the approach to adult learners has changed. The adults are less and less often perceived as people who learn less effectively. On the contrary, it is emphasized that adults, especially those with the above-average level of intelligence, can learn successfully into old age. What is more, adults often manifest a stronger intrinsic motivation to learn, allowing them to achieve equally good, or even better, learning results in comparison to young people. The aforementioned considerations clearly indicate that the age should not prevent the adults from active participation in the learning process. 


\section{Overview of Learning Theories}

Learning is an activity accompanying a human being since the dawn of history, and ever since philosophers, psychologists and educators have tried to explore its essence by presenting the results of their research and reflections in the form of learning theories.

There are many theories that explain the learning process in an internally consistent and logical way. In the further part of this article the main assumptions of behaviourism, cognitivism and constructivism as the most important traditional learning theories, as well as connectivism as an example of the theory which is a response to the challenges of modern education, are described.

Behaviourism focuses on objectively observable behaviours of learners, who are essentially passive. This theory operates on a principle: stimulus - response and assumes that by reinforcing appropriate and eradicating improper behaviour the learning process, understood as a new behaviour acquisition, occurs (Behaviorism, http://www.learningtheories.com). According to T. Shuell (2013) behaviourism explains the rote acquisition of information or the learning of physical and mental skills better than other theories.

Cognitivism puts the learner at the centre of cognitive processes. Learners are treated as rational beings that require active participation in order to learn, and act on the basis on thinking (Cognitivism, http://www.learningtheories.com). Cognitivism is focused on mental activities and understanding of complex material, and emphasized that learning occurred from the inside out rather than from the outside in (Shuell, 2013). Knowledge is seen as a schema or symbolic mental construction, and learning is understood as a change in the learner's schemata.

According to the assumptions of constructivism, learning is an active, contextualized process of constructing knowledge on the basis of personal experiences and hypothesis of the environment, which are continuously tested through social negotiations. To make sense of one's own experiences, people create and use their own rules and mental models (Constructivism, http://www.learning-theories.com). Constructivism departs from the creation of standardized curricula, and teaching is mainly conducted by solving problems. Teachers encourage learners to analyse, interpret, and predict information, as well as promote extensive dialogue among them.

Connectivism as a theoretical framework for understanding learning in the knowledge-based economy (Kop, Hill, 2008 , p. 2) which explains how information and communication technologies create new teaching and learning opportunities for people.

According to assumptions to this theory learning is a process of connecting specialized nodes or information sources which may reside in non-human appliances (Siemens, 2005, p. 7). Connections which enable people to learn more, are more important than their current state of knowing, therefore nowadays the ability to recognize connections between fields, ideas and concepts is a core skill, and ability to determine which information is important is especially vital for both teachers and learners. Teacher's role is to lead learners to information, answer questions to support their learning and encourage them to seek and share information (Connectivism /Siemens, Downes/, 2016).

In summary, briefly described learning theories present different approaches to teaching and learning, attributing different roles to teachers and learners, assigning different motives to them, proposing different techniques and methods of teaching and learning. Each theory has both proponents and opponents, using a wide array of arguments for or against a particular theory. And each of these theories brings something new, interesting and inspiring to teaching and learning processes, that in certain environments, circumstances, and in relation to certain groups of learners, can bring excellent results.

Behaviourism, cognitivism and constructivism are theories most often utilized in the creation of instructional environments. These theories, however, were developed in a time when learning was not influenced by technology (Siemens, 2005, p. 3). Connectivism, in turn, is the answer to today's educational challenges resulting from the rapid knowledge development, information chaos, ICT development, social networking, etc. Unambiguous indication which of these theories is the best is not possible. Practice shows in fact that usually skilful compilation of elements of different theories, that meets the specific needs of learners, brings the best results. As Drumlak states (2011, p. 32), the starting point in the discussion regarding the selection of the proper learning theory should be the awareness of reasons for learning.

\section{Pedagogical Versus Andragogical Way of Teaching - Similarities and Differences}

Considering characteristics of the learner's two main approaches to teaching process, namely pedagogy and andragogy, can be distinguished.

Pedagogy is defined as the art and science of teaching children (Knowles, 1980, p. 40) and deals with education 
conducted 'from above', in which the teacher dominates learners (Jarvis, 1985, pp. 50-51; Drumlak, 2011, p. 37). Pedagogy is based on the following assumptions: dependent personality of the learner, subjected-centred learning, extrinsic motivation, irrelevant learner's previous experience as a source for learning (Knowles et al., 1998, pp. 61-63).

In the pedagogical way of teaching learners are subject-oriented and they only need to know what the teacher teaches. The basic purpose of learning the material is to pass the course. Teacher's job is to fill the learners minds with their own information, and the learners are not encouraged to question what they are taught (McGrath, 2009, p. 101). The dominant pedagogical teaching method is the transmission of knowledge. However, according to Smith "pedagogy needs to be explored through the thinking and practice of those educators who look to accompany learners; care for and about them; and bring learning into life. Teaching is just one aspect of their practice" (Smith, 2012).

Andragogy is defined as the art and science of helping adults learn (Knowles, 1980, p. 43) and as "a concept of pedagogical approaches for adult learners in lifelong learning" (Yoshimoto et al., 2007, p. 75). Adults are specific learners as they are characterized by: self-direction, experience, readiness to learn, orientation on solving problems and intrinsic motivation to learn (Knowles, 1980, pp. 45-52). They learn best when they want or need to learn something, their individual learning style needs are met and their previous experience is valued and utilized. Adult learners need the conducive environment for learning and they want to have the opportunity to practice and apply what they have learned. They need time for assimilation of new information and feedback to evaluate progress towards their goals (Knowles, 1980, p. 57-58; Ozuah, 2005, p. 86). Adults learn more effectively at their preferred pace, not under time constraints (Turner, Helms, 1999, p. 545; Thorndike, 1950, p. 193). The pace of learning is affected by the following: their previous experiences, possessed talents or earlier education (Mikolajczyk, 2011).

Educators of adult learners are to help, guide, encourage, consult and to be a resource for learners. Their role is to help learners achieve full potential, their objective is to help people grow in the ability to learn, and their mission is to develop a widely understood conductive environment for human growth (Knowles, 1980, pp. 37-38).

The assumptions of andragogy are often criticized due to lack of empirical evidence to support them. However, critical opinions on andragogy do not discourage educators to apply it - many of them, in various settings, utilize the assumptions of andragogy in their educational efforts, either fully or in part (Blondy, 2007, p. 116).

Table 1 shows a comparison of pedagogy and andragogy due to the selected characteristics of both described above teaching concepts.

Table 1. Pedagogy vs. andragogy - a comparison

\begin{tabular}{|c|c|c|}
\hline Pedagogy & characteristics & Andragogy \\
\hline process of transmitting what is known & the understanding of education & lifelong process of continuing inquiry \\
\hline from above & education conducted.. & between equals \\
\hline transmission of information & teacher's role & helping learners learn \\
\hline $\begin{array}{l}\text { assimilate the content submitted by a } \\
\text { teacher }\end{array}$ & learner's role & active participation in the learning process \\
\hline dependent & learner's personality & independent \\
\hline teachers & $\begin{array}{l}\text { responsibility for what, how, when, why is to } \\
\text { be learned }\end{array}$ & teachers and learners \\
\hline irrelevant & the role of learner's experience & crucial (fundamental) \\
\hline when others say they ought to learn & learners readiness to learn & when they have a need to learn \\
\hline mainly extrinsic & motivation to learn & mainly intrinsic \\
\hline mainly teacher's & responsibility for results of education & mainly learner's \\
\hline $\begin{array}{l}\text { transmittal } \\
\text { (lecture, assigned reading, } \\
\text { presentations etc.) }\end{array}$ & primary techniques in education & $\begin{array}{l}\text { experiential } \\
\text { (laboratory, experiments, discussion, } \\
\text { simulations etc.) }\end{array}$ \\
\hline fairly standardized curriculum & learning programs organization & around life-application categories \\
\hline subcject-centered & learners' orientation to learning & problem-centred \\
\hline pass the course & goal of learning & develop competences \\
\hline
\end{tabular}

Source: own elaboration based on the literature.

Many authors highlight the fundamental difference in pedagogical and andragogical approach to the learning process (Davenort, 1987, pp. 18-20), while others think that pedagogy and andragogy are not necessarily mutually exclusive 
paradigms. According to Ozuah (2005, p. 84) andragogy "contains an appreciation and acceptance of pedagogy in many instances. [...] Pedagogy is an appropriate approach in situations where adult learners are truly dependent and have no relevant previous experience". In such a situation applying a pedagogical approach and providing information in a dependent way is a reasonable course of action. But over time andragogy practitioners would gradually move the learner toward increasing autonomy and self-direction (Ozuah, 2005, p. 84). The problem is "when pedagogical methods and practices are applied in whole or in part to situations that require andragogical dynamics" (Pew, 2007, p. 14).

\section{Selected Conventional and Unconventional Teaching Methods}

A teaching method is deliberately and systematically used method the teacher works with the learners, which enables them to master the knowledge and skills for practical purposes as well as to develop their cognitive abilities and interests. Each teaching method contains two main elements - the preparation of teaching material and work with the learners.

Teaching methods have didactic functions, as they: familiarize learners with new material, enable them to strengthen the acquired knowledge, enable the control and assessment of the degree of knowledge mastery.

The choice of a teaching method depends on many factors, but the most important is the characteristic of the learners. Educational content, work objectives and tasks, organization and resources the teacher intends to use also influence the choice of a teaching method. The use of a suitable method is also dependent on whether the learner masters the material on his own or in a group as well as on whether a group of people learns together for the first time, or the learners know each other and know methods which have yield the best results in the past. All these factors cause that sometimes the search for well-matched teaching method is not an easy task and takes a long time.

Nowadays activating teaching methods that stimulate learners' creativity are used more and more often. The process of creative teaching should be supported with methods which help to generate knowledge in a more efficient manner. There are numerous methods that made this possible - the choice of the right one depends on various factors and does not necessarily exclude the use of other method. When one method does not bring expected results, other method should be used.

Most people involved in the processes of education develop their own preferred learning styles and use methods by which they acquire knowledge individually. Learning styles can be correlated with used teaching methods, which strengthen the processes of knowledge acquisition. An overview of teaching methods is presented in table 2.

Table 2. Overview of the exemplary classifications of teaching methods

\begin{tabular}{||l|l||}
\hline \hline Author & Classifications of teaching methods \\
\hline Kupisiewicz & $\begin{array}{l}\text { - word-based method (lecture, story, talk, description, discussion, work with the book) } \\
\text { - method based on observation and measurement (demonstration, measurement) } \\
\text { - method based on learners' practical activities (laboratories, practical classes) } \\
\text { - activating method (brainstorming, situational method, problem method, staging) }\end{array}$ \\
\hline Okoń & $\begin{array}{l}\text { - method of knowledge acquisition - learning by assimilation (talk, lecture, discussion, work with a book) } \\
\text { - method of self-achieving knowledge - learning by discovery (case method, problem method, situational }\end{array}$ \\
& $\begin{array}{l}\text { - valorisation method - learning by experiencing (impressionistic and expressive methods) } \\
\text { - practical method - learning by doing (exercises, tasks) }\end{array}$ \\
\hline Lerner \& Statkin & $\begin{array}{l}\text { - reproductive method (demonstration, lecture, reading, TV, radio broadcasts) } \\
\text { - problem method (lecture, observation, work with a book, experiment, trip) } \\
\text { problem) }\end{array}$ \\
\hline Nowacki & $\begin{array}{l}\text { research method (learning the rules and phases of research, literature studies on a selected problem, } \\
\text { developing a plan of research, hypothesis verification, checking the result) }\end{array}$ \\
\hline \hline
\end{tabular}

Source: own elaboration based on: Teaching methods -http://www.uz.zgora.pl/ aszeleck/W6_METODY_NAUCZANIA. pdf 


\section{Methodology of the Research}

The objective of the study were cognitive, theoretical and methodological considerations focused on the development of social and intellectual capital through the use of different teaching methods in the development of the creative sector of SMEs. To achieve this goal, the research aimed at the estimation of the level of impact of particular teaching methods on the development of creativity in the organizations functioning in the creative sector was conducted. On the basis of the so-defined purpose, the following hypotheses were formulated:

H1. Teaching methods are an effective factor in stimulating creative activity - predicted probability of generating creative attitudes is higher if respondents and teachers use different teaching techniques, which stimulate creativity.

H2. The use of only selected teaching methods in a certain way affects the level and style of creativity among survey respondents.

H3. The most effective type of teaching methods is associated with their diverse, both conventional and unconventional, course and use in an educational process.

The study was based on qualitative and quantitative analysis of statistical data. To collect the statistical material the questionnaire method was used.

The study was addressed to people working in SME operating in the creative sector. For the purpose of this study activities characteristic for the creative sector were divided into four groups (Grochowski et al., 2012, p. 11; Figurska, Sokół, 2014, pp. 235-246). The first group encompasses creative activities of a cultural nature, which include activities that are rooted in creativity, skills and talent of the man, and at the same time are associated exclusively with the production of creative products (literature, visual arts, film, video, musical activities, performing arts, photography). The second group comprises creative activities of a functional character, resulting in commercial products. These creative activities include: advertising, architecture, publishing, design and fashion design, radio and television, computer software (including interactive entertainment software). The third group encompasses creative activities based on knowledge and includes: production and services in the field of ICT (except for the software) and R\&D. The fourth group includes the following creative economic activities: cultural institutions, art and antiques trade, media, higher education (activities related to the copyright exploitation).

A survey questionnaire contained a set of closed questions, which facilitated statistical elaboration of the results. To each organization belonging to the target research sample (located on the created address list) an e-mail addressed to the chairman, director or the owner of the company was sent, requesting filling out the questionnaires by them and their employees. After a week, a request was renewed by the same means of communication.

The analysis of the results of the research was based on the method of documents' examination as well as descriptive, analog and heuristic methods were used. In the process of statistical analysis of the data, the following coefficients were used: Chi^2 Pearson, T-Czuprow, V-Cramer, C-Pearson. The results of empirical study enabled both the achievement of objectives set in presented article and verification of proposed hypotheses.

The level of respondents' creativity was evaluated based on the results of the Drawing Test of Creative Thinking by Urban and Jellen (Karwowski, 2009). Results of this test were divided into 10 groups using descriptive statistics. On this basis stens were prepared, which were classified into three categories of results: (1) - low (0-25 points), (2) - medium (26-35 points) and (3)- high (more than 36 points). It should be noted that this division is arbitrary and therefore should be treated with due care.

Style of creativity was measured as a total result of the KAl questionnaire by Kirton (Karwowski, 2009), and a high result demonstrates innovation (1), but a low result - adaptability (2).

In sum, 911 people took part in the survey who were assigned to four above-identified groups forming the creative sector (table 3). The largest group was the first one, which consisted of 500 employees (55\% of the study group), and the least numerous was the fourth group which consisted of 36 respondents ( $4 \%$ of the study group).

Table 3. Respondents according to identified groups of the creative sector

\begin{tabular}{||c|c|c|}
\hline Group & Number of respondents & Percentage (\%) \\
\hline Group 1 & 500 & 55 \\
\hline Group 2 & 250 & 27 \\
\hline Group 3 & 125 & 14 \\
\hline Group 4 & 36 & 4 \\
\hline In total & 911 & 100 \\
\hline
\end{tabular}

Source: own study. 
Most organizations of the SMEs sector employing creative workers participated in the study focused their activities on domestic and regional markets. Only $26 \%$ of organizations offered their services or products on both domestic and foreign markets.

Women accounted for $57 \%$ of respondents. Study participants were aged $22-44$, but the largest group of them were young people (22-35 years). Respondents were a diverse group in terms of education. The period of managing organizations was in most cases short (up to 5-10 years), only one person has been running a business for over 15 years.

\section{The Results of the Study and Discussion}

One of the most important functions of the creative sector activity is undoubtedly a stimulation of development of regions and promotion of both increase of the competitiveness as well as innovativeness of the economy. Therefore, the theoretical considerations contributed to undertaking a research verifying theory.

The study covered the possibility of using andragogical teaching method according to criteria of the classification proposed by Kupisiewicz (Table 2.) in order to evaluate the relation of their most effective use with creativity of creative sector workers.

Therefore, the attempt to answer the question: Which of the andragogical teaching methods are most related and affect the level and style of creativity? was made. Hence, the level of creative abilities and creative style of creative workers were studied first, and then the correlation with used teaching methods was determined.

Table 4. The relationship between the level and the style of creativity

\begin{tabular}{|c|c|c|c|c|}
\hline & \multicolumn{4}{|c|}{$\begin{array}{l}\text { Level of creativity x Style of creativity } \\
\text { Chi^2 Pearson: } 32,1200, d f=2, p=, 000000 \\
\text { T-Czuprow: } 0,1579, V \text {-Cramer:0,18777, C-Pearson:0,18455 }\end{array}$} \\
\hline & \multirow[b]{2}{*}{ Level of creativity } & \multicolumn{2}{|c|}{ Style of creativity } & \multirow[b]{2}{*}{ In total } \\
\hline & & 1 & 2 & \\
\hline Number & 1 & 38 & 194 & 232 \\
\hline$\%$ from column & & $29,46 \%$ & $24,81 \%$ & \\
\hline$\%$ from row & & $16,38 \%$ & $83,62 \%$ & \\
\hline Number & 2 & 46 & 461 & 507 \\
\hline$\%$ from column & & $35,66 \%$ & $58,95 \%$ & \\
\hline$\%$ from row & & $9,07 \%$ & $90,93 \%$ & \\
\hline Number & 3 & 45 & 127 & 172 \\
\hline$\%$ from column & & $34,88 \%$ & $16,24 \%$ & \\
\hline$\%$ from row & & $26,16 \%$ & $73,84 \%$ & \\
\hline Number & The whole & 129 & 782 & 911 \\
\hline
\end{tabular}

Source: own study.

Data presented in the table no. 4 shows that $85,84 \%$ of respondents show adaptive style of creativity the remaining $14,16 \%$ show an innovative one. The majority of the respondents $(55,65 \%)$ show present an average level of creativity (2), the highest level of creativity is characteristic of the smallest group of the participants (18,88\%). Among the participants of the research with the highest level of creativity slightly more than $25 \%$ show innovative style, the respondents with average and low level of creativity the percentage of those using an innovative stale was $9,07 \%$ and $16,38 \%$ respectively.

The analysis of the results of the research showed that the correlation coefficient between the four distinguished teaching methods, and the style and the level of respondents' creativity, showed positive and significant correlations.

Table 5. Correlations between teaching methods and the level and style of creativity

\begin{tabular}{||l|c|c|c|c|c|}
\hline \multirow{2}{*}{ Teaching methods } & \multicolumn{3}{|c|}{ Level of creativity } & \multicolumn{2}{c|}{ Style of creativity } \\
\cline { 2 - 7 } & \hline 1 & 2 & 3 & 1 & 2 \\
\hline word-based method & $0,02^{*}$ & $0,10^{\star}$ & $0,09^{\star}$ & $0,21^{*}$ & $0,05^{\star *}$ \\
\hline \hline
\end{tabular}




\begin{tabular}{|l|l|l|l|l|l||}
\hline \hline method based on observation and measurement & $0,15^{\star}$ & $0,17^{*}$ & $0,19^{\star}$ & $0,07^{*}$ & $0,02^{*}$ \\
\hline method based on the learners' practical activities & $0,03^{*}$ & $0,02^{*}$ & $0,11^{*}$ & $0,12^{\star \star}$ & $0,09^{*}$ \\
\hline activating method & $0,02^{*}$ & $0,09^{*}$ & $0,09^{\star}$ & $0,26^{*}$ & $0,03^{* *}$ \\
\hline \hline
\end{tabular}

Source: own study.

Having analysed the relations existing between the teaching methods and the style of creativity the innovative style (1) has been proved to have the strongest correlation with word-based method $(0,21)$ and the activation method while it shows the weakest correlation with observation and assessment-based methods $(0,07)$. The adaptive (2) style has the strongest correlation with a method based on practical actions taken by the learners $(0.09)$, it shows the weakest correlation with observation and assessment-based methods $(0,02)$. It has been observed that word-based methods and activating methods have stronger correlation with innovative style; however, they are weakly correlated, although statistically important, with the adaptive style.

Having analysed the correlation between the specified teaching methods and the creativity level of the participants it has been observed that the observation and assessment-based method shows the strongest correlation with every level of creativity, it has also been observed that the higher level of creativity the stronger correlation.

In the method based on practical actions taken by the learners the strength of correlations is significantly stronger for the highest level of creativity than for the lower ones. As far as the word-based method as well as the activating method are concerned the correlation for the second and third level of creativity was comparable and at the same time considerably higher than for the first level of creativity.

To sum up, observation and assessment-based method shows a strong correlation with the level of creativity and a low one with the style of creativity. The word-based method and the activating method are very different, however, they both show similar correlation with both specific levels of creativity and creativity styles. As far as the method based on practical actions taken by the learners is concerned it is strongly correlated with the highest level of creativity and innovative style.

Table 6. The level and the style of creativity expected on the basis of used teaching methods

\begin{tabular}{|c|c|c|}
\hline Teaching methods & Level of creativity & Style of creativity \\
\hline word-based method & $\mathrm{R}=0,013 \mathrm{R}^{\wedge} 2=0,001$ & $R=0,24 R^{\wedge} 2=0,057$ \\
\hline $\begin{array}{l}\text { intrinsic motivation } \\
\text { extrinsic motivation }\end{array}$ & $F(1,909)=14,321^{*}$ & $F(1,909)=55,612^{\star \star}$ \\
\hline $\begin{array}{l}\text { method based on observation and } \\
\text { measurement } \\
\text { intrinsic motivation } \\
\text { extrinsic motivation }\end{array}$ & $\begin{array}{l}\mathrm{R}=0,039 \mathrm{R}^{\wedge} 2=0,001 \\
\mathrm{~F}(1,909)=1,4153^{*}\end{array}$ & $\begin{array}{l}\mathrm{R}=0,143 \mathrm{R}^{\wedge} 2=0,020 \\
\mathrm{~F}(1,909)=18,982^{\star \star \star}\end{array}$ \\
\hline $\begin{array}{l}\text { method on practical actions taken by the } \\
\text { learners } \\
\text { intrinsic motivation } \\
\text { extrinsic motivation }\end{array}$ & $\begin{array}{l}\mathrm{R}=0,101 \mathrm{R}^{\wedge} 2=0,010 \\
\mathrm{~F}(1,909)=9,3830^{\star \star \star}\end{array}$ & $\begin{array}{l}R=0,065 R^{\wedge} 2=0,004 \\
F(1,909)=3,9451^{* \star}\end{array}$ \\
\hline \begin{tabular}{|l|} 
activating method \\
intrinsic motivation \\
extrinsic motivation
\end{tabular} & $\begin{array}{l}R=0,0559 R^{\wedge} 2=0,003 \\
F(1,909)=2,8565^{*}\end{array}$ & $\begin{array}{l}R=0,204 R^{\wedge} 2=0,041 \\
F(1,909)=39,773^{\star \star \star}\end{array}$ \\
\hline
\end{tabular}

Source: own study.

Next, the correlation between teaching methods and the style as well as the level of creativity using the evaluation of all the participants was investigated.

The evaluation that implements a model of multiple regression was conducted using the level of motivation measured by means of Polish adaptation of Amaible Work Preference Inventory by Karwowski (2009), as well as the aforementioned teaching methods.

Using the aforementioned tool one can distinguish extrinsic and intrinsic motivation. It is a tool that consists of 30 statements that describe various points of view regarding learning or problem solving. The participant is to assess to what 
extent the content of every statement is true for them (on a scale from 4 - 'a given statement is true and I always or almost always act like that' to 1 - 'a given statement is completely untrue and I never or almost never act like that'). Both motivational orientations are structural in their nature. As far as the intrinsic motivation is concerned (15 statements) it consists of internal motivation (the source of motivation is located in an entity), challenge (willingness to take on difficult and new tasks) and pleasure and excitement (striving for emotional states referred to as flow) (Csikszentmihalyi, 1996). The structure of extrinsic motivation (15 statements) is described by means of external motivation (placing a motive in an external incentive), the ability to set goals and their accuracy and clarity.

The results of hierarchical regression analyses, with interactive effect for four distinguished teaching methods in the second step, are presented in Table 6.

The study included formulas that describe sought dependences. Among proven relations, a greater impact of teaching methods on the style of creativity than on the level of creativity was observed. It is worth noting that the results of regression models confirm significant relationships resulting from the correlation.

\section{Conclusions}

The subject of the research analyses was the search for relationships between representatives of the creative sector and teaching methods that are or may be used in the process of stimulating creativity as well as explicit and tacit knowledge development. Previously held assumptions presented in the form of three research hypotheses have been positively verified. Therefore, with all conviction a relationship between teaching methods and their effective impact on a stimulation of creative activity, which can result in a probability of generating creative attitudes, can be confirmed. The main conclusion of the results of the study is that the use of multiple teaching methods influences the level and style of creativity among survey participants in a certain way. The study has also shown that creative activities are related to the type of teaching methods, associated with their diverse, both conventional and unconventional, course and use in the educational process.

\section{References}

Behaviorism. [Online] Available: http://www.learning-theories.com/ behaviorism.html (May 30, 2016).

Blondy, L. C. (2007). Evaluation and Application of Andragogical Assumptions to the Adult Online Learning Environment, Journal of Interactive Online Learning, 6 (2).

Cognitivism. [Online] Available: http://www.learning-theories.com/ cognitivism.html( May 30, 2016).

Connectivism (Siemens, Downes). [Online] Available: http://www.learning-theories.com/connectivism-siemens-downes.html (May 25, 2016).

Constructivism. [Online] Available: http://www.learning-theories.com/ constructivism.html (May 30, 2016).

Csikszentmihaly M. (1996), The Creative Personality. In Psychology Today, July-August, 3-40.

Davenort, J. (1987). Is there any way out of the andragogy morass?, LifeLong Learning, 11 (3).

Drumlak, U. (2011). Proposal to use unconventional methods of accounting education in universities, Folia Pomeranae Universitatis Technologiae Stetinensis, Oeconomica, 287(63).

Figurska, I., Sokół, A. (2014). Optimization of Knowledge Management Processes through Benchmarking in Organizations, Mediterranean Journal of Social Sciences, 5 (27).

Grochowski, M., Dudek-Mańkowska, S., Fuhrmann, M., Zegar, T. (2012). The creative sector and public spaces in Warsaw, Mazowsze. Studia regionalne, 11.

Jarvis, P. (1985). The Sociology of Adult and Continuing Education, Croom Helm, Beckenham.

Karwowski, M. (2009). Exploring creativity: Study on the measurement of the level of creativity and style. Warsaw: APS.

Knowles, M. S., The Modern Practice Of Adult Education. From Pedagogy to Andragogy, Cambridge, New York 1980.

Knowles, M.S., Elwood, R., Holton III R., Swanson A. (1998). The Adult Learner: The Definitive Classic in Adult Education and Human Resource Development. 5th edition, New York: Heinemann.

Kop, R., Hill, A. (2008). Connectivism: Learning theory of the future or vestige of the past? International Review of Research in Open and Distance Learning, 9 (3).

Lundy, O., Cowling, A. (2000). Strategic Human Resource Management, Cracow: Oficyna Ekonomiczna.

McGrath, V. (2009). Reviewing the Evidence on How Adult Students Learn: An Examination of Knowles' Model of Andragogy, The Irish Journal of Adult and Community Education.

Mikołajczyk, K. (2011). How adults learn, that is what a coach should know about the specifics of vocational training participants, Ementor, 2 (39).

Ozuah, P. O. (2005). First, There Was Pedagogy And Then Came Andragogy, The Einstein Journal of Biology and Medicine, 27.

Pew, S. (2007). Andragogy and Pedagogy as Foundational Theory for Student Motivation in Higher Education, Student Motivation, 2.

Shuell, T. (2013). Theories of Learning, 2013, [Online] Available: http://www.education.com/reference/article/theories-of-learning (April, 
15, 2016).

Siemens, G. (2005). Connectivism: A Learning Theory for the Digital Age, International Journal of Instructional Technology and Distance Learning 2(1).

Smith, M. K. (2012). What is pedagogy? The encyclopaedia of informal education. [Online] Available: http://infed.org/mobi/what-ispedagogy (April, 13, 2016).

Thorndike, E.L. (1950). Adult learning, Warsaw: State Betting School Publishing.

Turner, J., Helms, D. (1999). Rozwój człowieka, WSiP, Warsaw.

Yoshimoto, K., Inenaga, Y., Yamada, H. (2007). Pedagogy and Andragogy in Higher Education - A comparison between Germany, the UK and Japan, European Journal of Education, 42 (1). 
ISSN 2039-2117 (online)

ISSN 2039-9340 (print)
Mediterranean Journal of Social Sciences MCSER Publishing, Rome-Italy
Vol 7 No 6 November 2016 